\title{
Proximate and Macro Element Composition of Four Fish Species from Lower River Benue Makurdi Benue State Nigeria
}

\author{
Ikape Simon Ihie ${ }^{1^{*}}$, Solomon Shola Gabriel ${ }^{2}$ and Ed-Idoko John ${ }^{3}$ \\ ${ }^{1}$ Department of Biological Sciences, Benue State University Makurdi Nigeria, Centre for Food Technology and Research \\ ${ }^{2,3}$ Department of Fisheries and Aquaculture, University of Agriculture, Makurdi, Nigeria
}

\begin{abstract}
Received: March 15, 2018; Accepted: April 4, 2018; Published: April 12, 2018
*Corresponding author: Ikape Simon Ihie, Department of Biological Sciences, Benue State University Makurdi Nigeria, Centre for Food Technology and Research, Nigeria. Tel: +2347066855581, E-mail: ikapesimon@gmail.com
\end{abstract}

\begin{abstract}
A study was conducted on four fresh water fish species: Protopterus annectens, Labeo coubie, Auchenoglanis occidentalis and Mormyrus rume from lower river Benue, Makurdi to determine the proximate and macro elements composition of these fish species from lower river Benue Makurdi. A total of 600 fish samples were collected, 50 samples from each species for the period of three months. Fish samples were collected and transported to the University of Agriculture Makurdi, Department of Fisheries and Aquaculture laboratory for analysis. Proximate analysis showed significant differences $(P<0.05)$ among the fish samples. Crude protein in fish samples was in the range (61.65-58.52\%) while fat was (8.14-8.34\%). Ash content was in the range (6.17-4.15\%). For Macro elements studied, Mercury was not discovered in Protopterus annectens and Auchenoglanis occidentalis. Lead value ranged from $0.09 \%$ to $0.03 \%$. Results for other macro element under study were all within permissible limit given by the World health organization.
\end{abstract}

Keywords: Proximate composition, Macro Elements, Protopterus annectens, Labeo coubie, Auchenoglanis occidentalis and Mormyrus rume.

\section{Introduction}

Fish is one of the most important sources of animal protein available in the tropics and has been widely accepted as a good source of protein and other vital nutrients for the maintenance of a healthy body [13]. The less developed countries capture $50 \%$ of the world harvest and a large proportion of the catch are consumed internally (FAO, 1985). In many Asian countries over $50 \%$ of the animal protein intake comes from fish while in Africa, the proportion is $17.50 \%$ [77]. In Nigeria, fish constitute $40 \%$ of the animal protein intake [55]. They have significant role in nutrition, income, employment and foreign exchange earning of the country. Fresh fish is a central point in fish for food utilization. The knowledge of fish composition is essential for its maximal utilization [68]. Fish is safer and healthier to be consumed when compared with goat, mutton, buffalo meat and chicken meat. Compared to other sources of protein, fish are well known to be excellent sources of protein which can be seen from amino acid composition and protein digestibility [44].

Proximate body composition is the analysis of water, fat, protein and ash content of the fish [45]. Proximate composition is a good indicator of physiology which is needed for routine analysis of fisheries [26]. Lipid is regarded as one of the most important food reserves and has led to the use of fat indices as a measure of relationship between percentage of water and fat [66]. A number of investigators have attempted to relate changes in body composition to seasonal variables $[27,38]$. The feeding frequency has an influence on body composition [26]. Body size or age has been shown to have a definite effect on body composition [8-10]. Several studies have shown significant changes in whole body composition or in the composition of specific organs or muscle tissues due to age, feeding frequency, migration, ration, sex, starvation and temperature $[48,76]$.

Heavy metals are serious pollutants in natural environment due to toxicity, persistence and bioaccumulation problems [72]. All heavy metals are potentially harmful to most organisms at some level of exposure and adsorption [80,47]. High concentration of heavy metals can result in poor water quality and low productivity of aquatic ecosystems $[33,75]$. The development in industrialization and technological advances in agriculture, has introduced various pollutants into the aquatic ecosystems, which serves as the ultimate sink for most metals. Waste water streams containing heavy metals are produced by many manufacturing processes and find their way into the environment [53]. Some research findings have shown that heavy metals in aquatic environment could accumulate in biota especially fish, the most common aquatic organisms at higher tropic level [57, 74]. Bioaccumulation in fish has been reported by many researchers [61, $81,25,51]$. Other factors for bioaccumulation has been reported to depend upon the rate of uptake through gut from food and the rate of excretion species differences as well as feeding habitat and trophic status of the fish [36]. Most heavy metals have no beneficial functions to the body and can be highly toxic. If enter the body through inhalation, ingestion and skin can accumulate in the body tissue faster than the body's detoxification pathways 
and disposition [29]. High concentration exposure, overtime, can reach toxic concentration at low levels $[63,7]$. Fish is a valuable and cheap food item and source of protein to man. Concern about heavy-metal contamination of fish has been motivated largely by adverse effects on humans, given that fish consumption primary route of heavy metal exposure [52].

Since there is no formal control of effluents discharged into the river Benue, it is important to monitor the levels of metals contaminants in the river Benue fish and assess the suitability for domestic uses. In order to effectively control and manage water pollution due to heavy metals, it is important to have a clear understanding of the distribution and profiles of heavy metals in the biota [65].

Therefore, the present work aimed to determine the proximate and Macro elements composition of four selected fish species Protopterus annectens, Labeo senegalensis, Mormyrus reme and Auchenoglanis occidentalis from lower river Benue Makurdiand evaluate the hazards and toxicity to fish and consumers in general.

\section{Material and Methods}

\section{Sampling Site}

The fish samples were collected from River Benue at Wadata Market, Makurdi the capital of Benue State, Nigeria, located at longitude 7o $43^{\prime} \mathrm{N}$ and latitude $8^{\circ} 32^{\prime} \mathrm{E}$. Benue River is the major tributary of the Niger River and it is approximately 1,400 $\mathrm{km}$ long and is almost entirely navigable during the summer months. As a result, it is an important transportation route in the regions through which it flows. It rises in the Adamawa Plateau of northern Cameroon, from where it flows west, and through the town of Garoua and Lagdo Reservoir, in to Nigeria south of the Mandara mountains, and through Jimeta, Ibi and Makurdi before meeting the Niger at Lokoja. The river's largest tributary is the Mayo Kebbi, which connects it with the Logone River (part of the Lake Chad system) during floods. Other tributaries are Taraba River and River Katsina Ala River Benue divides the town into the North- and South-bank and flows all year round though the water volume fluctuates with season. The river overflows its banks during the rainy season (May-October), but decreases drastically in volume leaving tiny island in the middle of the river during the dry season (November-April). The river contains several species of fresh water fishes of different families such as Protopteridae, Claroteidae, Mormyridae and family Cyprinidae.

\section{Sample Collection}

A good number of fish samples of Protopterus annectens, Labeo coubie, Auchenoglanis occidentalisand Mormyrus rume were obtained from lower river Benue Makurdi Benue state Nigeria. The fish samples were kept in cold iced box and transported to the Department of Fisheries and Aquaculture Laboratory University of Agriculture Makurdi Nigeria for Proximate analysis.

\section{Proximate Composition}

Proximate composition of fishes was determined using AOAC methods (1990). Moisture content was measured by weighing differences before and after oven drying at $100-105^{\circ} \mathrm{C}$ for $16 \mathrm{~h}$.
Lipid determination was carried out using the modified Bligh and Dyer procedure (1959), the ash content of the fish was determined by igniting the sample at $550^{\circ} \mathrm{C}$ for $5-6$ hours until the sample was completely free from carbon particles in a carbonite muffle furnace while the total nitrogen was determined by Kjedahl method as described by AOAC, (1994) and a factor of 6.25 was used for converting the total nitrogen to crude protein of the fish sample.

\section{Determination of Macro Elements}

The following macro elements (Nitrogen, Phosphorus, Potassium, Sodium, Calcium, Magnesium, Iron, Lead and Mercury) of the four fish samples were determined directly using Atomic Absorption Spectrophotometer (AAS) in the laboratory. This process involves the absorption by free atoms of an element of light at a wavelength specific to that element.

\section{Instruments Used}

1. Flame Photometer (FP 640) was used to determine Sodium (Na) and Potassium (K);

2. Spectrophotometer: (B \& L Spectrome 70) was used to determine Phosphorus (P);

3. Atomic Absorption spectrophotometer (AAS; BULK SCIENTIIFC) VGP-210 [Mg, Ca, Fe, Pb, and $\mathrm{Hg}$ ]

\section{Statistical Analysis}

All data were analyzed by one-way ANOVA analysis using SPSS 17.0 for windows. A value of $P<0.05$ was used to indicate significant differences.

\section{Results and Discussion}

Mean percentage for moisture protein, fat, ash and carbohydrate content of fishes are given in table 1 . The four fishes had moisture content ranging from $3.99 \%$ to $5.26 \%$ (Table 1). Similar result was reported by [3]. The proximate composition of Auchenoglanis occidentalis showen couragingly high crude protein contents of $61.65 \%$ while it was least with Protopterus annectens $58.52 \%$ (Table 1). The relatively high to moderate percentage crude protein in Auchenoglanis occidentalis among others could be attributed to fish's consumption or absorption capability and conversion potentials of essential nutrients from their diet or their local environment into such biochemical attributes needed by the organisms body. Adewoye and Omotosho et, al. also attributed high protein content in fish to their local environment and biochemical attributes of the fish. Abdullahi SA also opened that the protein content in fish might vary with species due to certain factors such as the season of the year, effect of spawning and migration, food available etc [1].

All the species in this study had high moisture content in the range of (5.12\%-5.26\%) except for Auchenoglanis occidentalis that had moisture content of (3.99\%). This could be as a result of water absorption capability and the source of heat used in the processing. High moisture contents have been similarly reported in other freshwater species by [1, 2, 30]. Differentiation in moisture and lipid content between dorsal and ventral portions 
Table 1: Proximate Composition of Selected Fish Species from Lower River Benue

\begin{tabular}{|c|c|c|c|c|c|}
\hline Proximate Component & Protopterus annectens & Auchenoglanis occidentalis & Labeo cubie & Mormyrus rume & P-Value \\
\hline Moisture & $5.26 \pm 0.17^{\mathrm{b}}$ & $3.99 \pm 0.47^{\mathrm{a}}$ & $5.12 \pm 0.41^{\mathrm{b}}$ & $5.23 \pm 0.14^{\mathrm{b}}$ & 0.07 \\
\hline Ash & $4.88 \pm 0.13^{\mathrm{ab}}$ & $4.15 \pm 0.93^{\mathrm{a}}$ & $6.17 \pm 0.19^{\mathrm{b}}$ & $5.74 \pm 0.19^{\mathrm{ab}}$ & 0.07 \\
\hline Lipid & $8.14 \pm 0.43^{\mathrm{bc}}$ & $6.62 \pm 0.12^{\mathrm{a}}$ & $7.32 \pm 0.17^{\mathrm{ab}}$ & $8.34 \pm 0.17^{\mathrm{c}}$ & 0.01 \\
\hline Fiber & $7.77 \pm 0.33^{\mathrm{a}}$ & $6.85 \pm 0.58^{\mathrm{a}}$ & $6.75 \pm 0.22^{\mathrm{a}}$ & $7.53 \pm 0.18^{\mathrm{a}}$ & 0.2 \\
\hline Protein & $58.52 \pm 0.64^{\mathrm{a}}$ & $61.65 \pm 0.52^{\mathrm{b}}$ & $60.00 \pm 0.30^{\mathrm{ab}}$ & $59.45 \pm 0.49^{\mathrm{a}}$ & 0.01 \\
\hline NFE & $15.47 \pm 1.08^{\mathrm{ab}}$ & $16.74 \pm 0.64^{\mathrm{b}}$ & $14.65 \pm 0.43^{\mathrm{ab}}$ & $13.72 \pm 0.44^{\mathrm{a}}$ & 0.08 \\
\hline
\end{tabular}

*Mean in the same row with different superscripts differ significantly $(\mathrm{P}<0.05)$

of three farmed fish species has also been reported by [69]. The ash content of Protopterus annectens, Labeo coubie, and Mormyrus rume were generally low $(4.88 \%-6.17 \%)$ and it was significantly $(P<0.05)$ lower with Auchenoglanis occidentalis $(4.15 \%)$. The crude fat also ranged from $(7.32 \%-8.34 \%)$ and was least with Auchenoglanis occidentalis (6.62\%). Abdullahi reported higher values (30.0-31.3/100g) from Chrysichthys nigrodigitatus, Bagrus filamentosus and Auchenoglanis occidenntialis.

There was no significant differences $(P<0.05)$ in the crude fiber for all the fish species under this study. Negligible amounts of these nutrients have been reported by other authors [54, 30].

\section{Macro Element Composition}

Results of macro elements composition from this study revealed significant differences $(P<0.05)$ in the distribution of Macro elements among the four the studied species of fish. There observed variation in the mineral contents of the four species studied. The Nitrogen, Phosphorus, Potassium, Sodium, Calcium, Magnesium, Iron, Lead and Mercury contents varied among these species. This observation agrees with the reported work of Oladimeji and Sadiku who studied the mineral constituents of three freshwater fish species Table 2 [56].
The Calcium, Phosphorus and Magnesium values in this study were higher than other macro elements analyzed for the four species. This observation agrees with the similar work of S.G Solomon and Akogu C.C. (2005). Who reported high level of Calcium and Phosphorus in Protopterus annectens, Labeo senegalensis and Auchenoglanis occidentalis. Accumulation of different macro elements depends on many factors such as the physiological needs, feeding habits and genetic composition, sex of each fish species and the biochemical significant role of each metal [40]. The high levels of these two elements ( $\mathrm{P}$ and $\mathrm{Mg}$ ) in these fish species studied may be attributed to the rate in which they are available in the water body and the ability of the fish to absorb these organic elements from their diet and the environment where they live [3].

Eyo (2001) opened that, mineral content of fish makes it unavoidable in the diet since mineral contribute great good health. $\mathrm{Pb}$ was the most common toxic Macro element in the samples analyzed followed by $\mathrm{Hg}$. The level of $\mathrm{Pb}$ and $\mathrm{Hg}$ was significantly $(P<0.05)$ different among the four species. Protopterus annectens was observed to contain the highest level of Lead $(0.09 \mathrm{mg} / \mathrm{kg})$ compared to the other species. The main reason could be the feeding habit and habitat of P. annectens. This result disagreed with the findings of Elagba and Mohamed that

Table 2: Macro Element Compositions of Selected Fish Species from Lower River Benue

\begin{tabular}{|c|c|c|c|c|c|c|}
\hline Macro elements & $\begin{array}{c}\text { Protopterus } \\
\text { annectens }\end{array}$ & $\begin{array}{c}\text { Auchenoglanis } \\
\text { occidentalis }\end{array}$ & Labeo cubie & $\begin{array}{c}\text { Mormyrus } \\
\text { rume }\end{array}$ & $\begin{array}{c}\text { WHO Permissible } \\
\text { Limit }\end{array}$ \\
\hline Nitrogen (N) & $0.41 \pm 0.01^{\mathrm{c}}$ & $0.00 \pm 0.00^{\mathrm{a}}$ & $0.33 \pm 0.03^{\mathrm{b}}$ & $0.36 \pm 0.01^{\mathrm{bc}}$ & $1.00 \pm 0.00^{\mathrm{d}}$ & 0 \\
\hline Phosphorus (P) & $4.88 \pm 0.30^{\mathrm{b}}$ & $6.05 \pm 0.37^{\mathrm{c}}$ & $4.34 \pm 0.26^{\mathrm{b}}$ & $4.03 \pm 0.40^{\mathrm{b}}$ & $0.10 \pm 0.00^{\mathrm{a}}$ & 0 \\
\hline Potassium (K) & $0.29 \pm 0.02^{\mathrm{ab}}$ & $0.34 \pm 0.02^{\mathrm{b}}$ & $0.27 \pm 0.02^{\mathrm{a}}$ & $0.23 \pm 0.01^{\mathrm{a}}$ & $2.00 \pm 0.00^{\mathrm{c}}$ \\
\hline Sodium (Na) & $0.26 \pm 0.01^{\mathrm{bc}}$ & $0.27 \pm 0.02^{\mathrm{c}}$ & $0.22 \pm 0.01^{\mathrm{ab}}$ & $0.21 \pm 0.01^{\mathrm{a}}$ & $10.00 \pm 0.00^{\mathrm{d}}$ & 0 \\
\hline Calcium Ca) & $4.64 \pm 0.28^{\mathrm{a}}$ & $4.79 \pm 0.29^{\mathrm{a}}$ & $4.84 \pm 0.18^{\mathrm{a}}$ & $4.74 \pm 0.20^{\mathrm{a}}$ & $10.00 \pm 0.00^{\mathrm{b}}$ & 0 \\
\hline Magnesium (Mg) & $3.89 \pm 0.24^{\mathrm{a}}$ & $4.29 \pm 0.25^{\mathrm{a}}$ & $3.64 \pm 0.22^{\mathrm{a}}$ & $3.61 \pm 0.22^{\mathrm{a}}$ & $10.00 \pm 0.00^{\mathrm{b}}$ \\
\hline Iron (Fe) & $0.36 \pm 0.02^{\mathrm{bc}}$ & $0.41 \pm 0.03^{\mathrm{c}}$ & $0.31 \pm 0.02^{\mathrm{ab}}$ & $0.27 \pm 0.02^{\mathrm{a}}$ & $1.00 \pm 0.00^{\mathrm{d}}$ & 0 \\
\hline Lead (Pb) & $0.09 \pm 0.01^{\mathrm{c}}$ & $0.06 \pm 0.00^{\mathrm{b}}$ & $0.12 \pm 0.00^{\mathrm{d}}$ & $0.03 \pm 0.00^{\mathrm{a}}$ & $0.20 \pm 0.00^{\mathrm{e}}$ \\
\hline Mercury (Hg) & $0.00 \pm 0.00^{\mathrm{a}}$ & $0.00 \pm 0.00^{\mathrm{a}}$ & $0.01 \pm 0.00^{\mathrm{b}}$ & $0.02 \pm 0.00^{\mathrm{c}}$ & $0.01 \pm 0.00^{\mathrm{b}}$ & 0 \\
\hline
\end{tabular}

"Mean in the same row with different superscripts differ significantly $(\mathrm{P}<0.05)$ 
Protopterus annectens contain least level of most of heavy metals in both tissues and head compared to the other species because it normally lives on flood plains, and when these dry up it secretes a thin slime around itself which dries into a cocoon [31]. So the fish is not continuously exposed to pollutants like other species. Results also reveals the levels of Mercury in Mormyrus rume to be significantly high $(P<0.05)$ compare to other fish species. This observed increase in Mormyrus rume, $(0.02 \mathrm{Mg} / \mathrm{kg})$ could be as result of its feeding habitat and its mode of feeding. Mormyrus rume has an inferior mouth (downturn mouth) which enables it to feed on the debris or the organic matters deposited into the river and accumulate at the bottom of the river. This observation is in agreement with the work of Amoo et, al. who reported high increase of $\mathrm{Hg}$. in Mormyrus rume due to pollution from sewage effluents [12]. Generally, heavy metal concentrations in the muscles of freshwater fish vary considerably among different studies possibly due to differences in metal concentrations and chemical characteristics of water from which fish were sampled, ecological needs, metabolism and feeding patterns of fish, and also the season in which studies were carried out $[61,80,6,51$, $59,50]$. The variation in Macro element concentrations could also be due to the presence of major sources of metal pollution, intensive human activity and discharge of municipal domestic waste and effluents.

Fish are often at the top of the aquatic food chain and have the tendency to concentrate large amount of some heavy metals from the water [46]. Bioaccumulation of heavy metals is toxic to fish $[24,19] . \mathrm{Pb}$ and $\mathrm{Hg}$ are considered as potential toxic elements. Metal stresses were reported to cause reproduction failure and losses in fish populations [5, 64]. The gills serve as respiratory organs through which ions are absorbed [42]. Fish can absorb metals from both the surrounding water and from their contaminated food and bioaccumulate them in their tissue. Some metals are essential, but at high concentrations, they can be toxic to fish, cause mortality, growth retardation, and reproductive impairment [5, 64]. Even If the minerals contents is lower than threshold values indicated by WHO (1996), contamination of aquatic ecosystems should be expected through bioaccumulation.

\section{Conclusion}

The result obtained in this study has provided scientific information and detailed knowledge of the proximate composition of these four important selected fish species. The results showed that the fish species had high quality protein, essential amino acids and fatty acids. Overall, Auchenoglanis occidenntialis appears to be best as diet for humans due to its relatively high protein and nutrient components. Therefore consumption of it is good for people's health.

The concentrations of macro elements in the body of fish depend in most cases on the biological factors, such as the species. In the case of iron depends also on the feeding type because predatory fish contain less iron than non-predatory fish.

The present studies has added information that the fishes are a good sources of macro elements that may contribute to health, growth and development of human beings and a safe food from environment concern due to negligible level of toxic elements. Although, the results obtained from the concentration of the Macro elements in selected fish species from the study area were below the permissible limit of World Health Organization (WHO), it does not mean the fish are free from the danger posed on consumers due to their bio accumulative nature in human and aquatic environment.

However, results will be important for the nutritionists and researchers for improving processing. It is also helpful for similar academic studies and to prepare tables of compositions of food.

\section{References}

1. Abdullahi SA. Investigation of Nutritional status of Chrysichthys nigrodigitatus, Barus filamentous and Auchenoglanis occidentals: Family Barigdae. Journal of Arid Zone Fisheries. 2001;1:39-50.

2. Abdullahi SA. Nutrient content of Citharinus citharus and Citharinus lates. Family: Citharinidae (Geoffery). Journal of Pure Applied Science.1999;2(1):65-68.

3. Adewoye SO, Omotosho JS. Nutrient Composition of some freshwater fishes in Nigeria. Biosci Res Commun. 1997;11(4):333-336.

4. Adewoye SO, Fawole 00, Omotosho JS. Concentrations of selected elements in some fresh water fishes in Nigeria. Science Focus. 2003;4:106-108.

5. Adham KG, Hasan IF, Taha N, Amin T. Impact of hazardous exposure e to metals in the Nile and Delta Lakes on the Catfish, Clarias Lazera. Environmental Monitoring and Assessment. 1999;54(2):107-124.

6. Ahmed A, Dodo A, Bouba AM, Clement S. Minerals and heavy metals in water, sediments and three fish species (Tilapia nilotica, Silurus glanis and Arius parkii) from Lagdo Lake, Cameroun. Journal of Fisheries International. 2010;5(3): 54-57.

7. Akan JC, Abdulrahman FI, Sodipo OA, Akandu PI. Bioaccumulation of some heavy metals of six fresh water fishes caught from Lake Chad in Doron Buhari, Maiduguri, Bornno State Nigeria. Nigerian Journal of Applied Sciences and Environment Management. 2009;4:103-114.

8. Ali M, Iqbal F, Salam A, Iran S, Athar M. Comparative study of body composition of different fish species from brackish water pond. 2005;2(3):229-232.

9. Ali M, Iqbal R. Rana SA, Athar M, Iqbal M. Effect of feed cycling on specific growth rate, condition factor and RNA/DNA ratio of Labeo rohita. African Journal of Biotechnology. 2006;5(17):1551-1556.

10.Alim M, Iqbal F, Salam A, Sial F, Athar M. Comparative study of body composition of four fish species in relation to pond depth. International Journal of Environmental Science Technology. 2006;2(4): 359 -364.

11.Ambedkar G, Muniyan M. Accumulation of metals in the five commercially important freshwater fishes in Vellar River, Tamil Nadu, India. Archives of Applied Science Research. 2011;3(3):261-264.

12.Amoo IA, Adebay OT, AJ Lateef. Evaluation of heavy metals in fishes, water and sediments of Lake Kainji, Nigeria. Journal of Food, Agriculture \& Environment. 2005;3(1):209.

13.Andrew AE. Fish Processing Technology. University of Ilorin press, Nigeria. 2001;7-8

14.Anim AK, Ahialey EK, Duodu GO, Ackah M, Bentil NO. Accumulation profile of heavy metals in fish samples from Nsawam, along the Densu River, Ghana. Research Journal of Environment and Earth Science. 2011;3:56-60. 
15.AOAC, (1990). Official analysis method of AOAC international (16th ed.) USA.

16.AOAC Association of Official Analytical chemistry (AOAC):Official methods of analysis of the Association of Official Analytical Chemists, Vols I \& II, Association of Analytical chemists, Arlington, 1994;128.

17.Apha. American Public Health Association Standard methods for the examination of water and wastewater (20th ed). New York, American Public Health Association. Washington DC. 1998.

18.Authman MMN. Oreochromis nilotica as a biomonitor of heavy metals pollution with emphasis on potential risk and relation to some biological aspects. Global Veterinaria. 2008;2(3):104-109.

19.Ayotunde EO, Offen BO. Heavy metals profile of water, sediment and freshwater catfish Chrysichthys nigrodigtalus (Siluriformes, Bagridae) of Cross River, Nigeria. Revista de Biologia Tropical. 2012;60(3):12-20.

20.Bligh EG and Dyer WJ. A rapid method for total lipid extraction and purification. Canadian Journal of Biochemical and Physiology.1959;37(8):911-917.

21.Bogut I. Water pollution by heavy metals and their impact on fish and human health, Hrvatske Vode. 1997;5:223-229.

22.BURGRESS GHO. Increasing the direct consumption of fish. In: WW Pirie (Edu). Food Protein Sources. International Biological Programme 4. Cambridge University Press, Cambridge, 1975;187-200.

23.Castro-Gonzeza IM, Méndez-Armentab M. Heavy metals: Implications associated to fish consumption. Environ Toxicol Pharmacol. 2008;26(3): 263-271. doi: 10.1016/j.etap.2008.06.001

24.Chattopadhyay B, Chatterjee A and Mukhopadhyay SK. Bioaccumulation of metals in the East Calcutta wetland ecosystem. Aquatic Ecosystems Health Management. 2002;5:191-203.

25.Christopher E, Vincent O, Grace I, Rebecca E, Joseph E. Distribution of heavy metals in bones, gills, livers and muscles of (Tilapia) Oreochromis niloticus from Henshaw Town Beach Market in Calabar, Nigeria. Pakistan Journal of Nutrition. 2009;8(8):1209-1211. doi: 10.3923/ pjn.2009.1209.1211

26.Cui Y, Wooth RJ. Effect of ration, temperature and body size on the body composition, energy content and condition of Minnow (Phoxinus phoxinus L). 1988;32(5):749-764

27.Dawson AS, Grimm AS. Quantitative seasonal changes in the protein, lipid and energy content of the carcass, ovaries and liver of adult female plaice, (Pleuronectes platessa L). Journal Fish Biology. 1980;16(5):493504

28.Dural M, Goksu MZ and Ozak AA. Investigation of heavy metal levels in economically important fish species captured from the Tuzla Lagoon. Food Chemistry. 2007;102(1):415-421.

29.Ekpo KE, Asia IO, Amayo KO, Jegede DA. Determination of lead, cadmium and mercury in surrounding water and organs of some species of fish from Ikpoba river in Benin city, Nigeria. International Journal of Physiological Sciences. 2008; 3:289-292.

30.Effiong BN and Tafa JL. Proximate composition of nutrients in adult Clarias gariepinus, Heterobranchus longifilis and their hybrid. Proceedings of the 20th Annual conference of Fisheries Society of Nigeria, 2005;550-553.

31.Elagba HA, Mohamed D. Bioaccumulation of Some Heavy Metals in Tissues and Head of Commercial Nile Fish in Sudan. Intl J Aquaculture. 2014;4(20):118-122. doi: 10.5376/ija.2014.04.0020
32.Hardy R, Smith JGM. Food and Agric Org. World catch and trade of Fisheries and products in 1984, Info fish marketing Digest. 1985.

33.Food and Agriculture Organization (FAO). Report of the third Session of Working Party on Pollution and Fisheries, Accra, Ghana, 1991, FAO Fisheries Report. 1992;471:43.

34.Gallagher ML, Harrel ML and Rulifson RA. Variation in lipid and fatty acid contents of Atlantic Croaker, Stiped Mullet and Summer Flounder. Transactions of the American Fisheries Society. 1991;120(5): 614- 619.

35. Helawell JM. Biological Indicators of Freshwater Pollution and Environmental Management, Elsvier Applied Science Publisher, Londo, 1986.

36.Huang BW. Heavy metal concentrations in the common benthic fishes caught from the coastal waters of Eastern Taiwan. Journal of food and drug analysis. 2003;11(4): 324-330.

37.Hui UH. Meat science and Application. CRA press pp. 704. Int J Environ Sci Technol. 2001;2:229-232. J Fish Biol. 32: 749-764

38.Jarboe HH, Grant WJ. The effect of water velocity on the growth, dressout and body composition of channel catfish, Ictalurus punctatus raised circular tanks. Journal of Applied Aquaculture. 1996;6(3):13-21.

39.Javed M, Hayat S. Fish as a bioindicator of freshwater contamination by Metal. Pakistan Journal of Agriculture Science. 1998;35:11-15.

40.Kamaruzzaman YB, Ong CM, Rina ZS. Concentration of $\mathrm{Zn}, \mathrm{Cu}$ and $\mathrm{Pb}$ in some selected marine fishes of the Pahang coastal waters, Malaysia. American Journal of applied sciences. 2010;7(3): 309-314.

41.Karadede-Akin H, Unlu E. Heavy metal concentrations in water, sediments, fish and some benthic organisms from Tigris river, Turkey. Environment Monitoring and Assessment. 2007;131(1-3):323-337.

42.Khan B, Khan H, Muhammad S, and Khan T. Heavy metal concentration trends in three fish species from Shah Alam River (Khyber, Pakhtunkhwa Province, Pakistan). Journal of Natural and Environmental Sciences. 2012;3(1):1-8

43.Klavins M, Potapovics O, Rodinov V. Heavy metals in fish from Lakes in Latvia: Concentrations and trends of changes. Bull Environ Contam Toxicol. 2009;82(1):96-100. doi: 10.1007/s00128-008-9510-x

44.Louka NF, Juhel V, Fazilleau, Loonis P. A novel colorimetry analysis used to compare different drying fish processes. Food control. 2004;15(5):327-334.

45.Love Rm (1980). The Chemical Biology of Fishes. Vol II. Academic press London

46.Mansour SA, Sidky MM. Ecotoxicological studies. 3. Heavy metals contaminating water and fish from Fayoum Governorate, Egypt. Food Chemistry.2002;78(1): 15-22.

47.Marcovecchio JE. The use of Micropogonias furnieri and Mugil liza as bioindicators of heavy metals pollution in La Plata River Estuary, Argentina. Sci Total Environ. 2004;323(1-3):219-226

48.Millikin MR. Effects of dietary protein concentration on growth, feed efficiency and body composition of aged striped bass. Trans Am Fish Soc. 1982;111(3):373-378.

49.Mohamed EAS, Gad NS. Environmental pollution-induced biochemical changes in tissues of TilapiaZilli, Solea vulgaris and Mugil capito from Lake Qarun, Eygpt. Global Veterinaria. 2008;2(6): 327-336.

50.Mohammed EHA, Osman AR. Heavy metals concentration in water muscles and gills of Oreochromis niloticus collected from the sewagetreated water and the White Nile. International Journal of Aquaculture. 2014;4(6):36-42. 
51.Njogu PM, Keriko JM, Wanjau RN, Kitetu JJ. Distribution of heavy metals in various lake matrices; water, soil, fish and sediments: A case study of the lake Naivasha Basin, Kenya. Journal of Agriculture, Science and Technology. 2011;13(1):17-24.

52.Nsikak UB, Joseph PE, Akan BW, David EB. Mercury accumulation in fishes from tropical aquatic ecosystems in the Niger Delta, Nigeria. Current Science. 2007;92(6):781-785.

53.Ogbeibu AE, Ezeunara PU. Ecological impact of brewery effluent on Ikpoba River using the fish communities as bioindicators. Journal of Aquatic Research. 2002;17(1): 35-44

54.Oladele AK, Gabriel LM, Ibanga UI. Proximate composition and selected Heavy metals concentration of smoked catfish (Clarias gariepinus) and Tilapia (Oreochromis niloticus) around Lake Kainji, Nigeria. Proceedings of the 20th Annual conference of Fisheries Society of Nigeria, 14th-18th Nov.2005pp 400-402.

55.Olatunde AA. Approach to the study of fisheries biology in Nigeria inland water. Proceedings of the International conference of two decades of research in lake Kainji. 1998;338-541.

56.Oladimeji AA, Sadiku SOE. Mineral Constituents of Latest niloticus (L) Synodontis schall (Broch and Schneider) and Sarotherodon galilaeus (Trewaves) from Zaria (Nigeria) Dam. Journal of Animal production Research 1991;11(1):45-52.

57.Olaifa AK, Adelaja AA, Owolabi AG. Heavy Metal contamination of Clarias gariepinusfrom a lake and fish farm in Ibadan, Nigeria. African Journal of Biomedical Research. 2004;7(3):145-148.

58.0lowu RA, Ayejuyo 00, Adewayi GO, Adejoro IA, Denloye AAB Babatunde AO, et al. Determination of heavy metals in fish tissues, water and sediment from Epe and Badagry Lagoons, Lagos, Nigeria. E-Journal of Chemistry. 2010;7(1): 215-221.

59.0paluwa OD, Aremu MO, Ogbo LO, Magaji JI, Odiba IE. Assessment of heavy metals in water, fish and sediments from UKE Stream, Nasarawa State, Nigeria. Current World Environment. 2012;7(2):213-220.

60.0zturk M, Ozozen G, Minareci O, Minareci E. Determination of heavy metals in fish, water and sediment of Avsar Dam Lake in Turkey. Journal of Environmental Health Science and Engineering. 2009;6(2): 73-80.

61.Papagiannis I, Kagalou I, Leonardos J, Petridis D, Kalfakaou V. Copper and zinc in four freshwater fish species from Lake Pamvotis (Greece). Environ Int. 2004;30(3):357-362.

62.Paulami M, Banerjee S. Fate of metals in fish under variable sewage input in fish ponds. International Journal of scientific Research Publications. 2012;2(6):1-13

63.Ploetz DM, Fitts BE, Rice TM. Differential accumulation of heavy metals in muscles and liver of a marine fish (King Mackerel, Scomberomorus cavalla, Cuvier) from the Northern Gulf of Mexico, USA. Bulletin of Environment Contamination and Toxicology. 2007;78(2): 134-137.

64.Saeed MS, Shaker MI. Assessment of heavy metals pollution in water and sediment and its effect on Oreochromis niloticus in the Northen Delta lakes Egypt, 8th International Symposium on Tilapia in Aquaculture. 2008;475-490.

65.Sabo A, Nayaya AJ, Galadima AI. Assessment of some heavy metals in water, sediment and freshwater mudfish (Clarias gariepinus) from River Gongola in Yamaltu-Deba, Gombe, Nigeria. International Journal of Applied Sciences. 2008;2:6-12.
66.Salam A, Davies PMC. Body composition of Northern Pike Esox licius L. in relation to body size and condition factor. Fish Res. 1994;19(34):193-204.

67.Siaw CL, ldrus AZ, Yu SY. Intermediate technology for fish cracker ('Keropok") production. J food Technol. 1985;20: 17-21.

68.Silva JJ, Chamul RS. Composition of marine and fresh water finfish and shell fish species and their products. In: RE Martin, EP Carter, EY Flick and LM Davis (Eds) Marine and fresh water products handbook, Lancaster, Pennsylvania, USA: Technomic Publishing Company. 2000;31-46

69.Silvia T, Alessio B, Pier PP, Anna B. Nutritional traits of dorsal and ventral fillets from three farmed fish species. Food chemistry.2006;98(1)104-111.

70.SPSS, Statistical Package for Social Science, Version 16.0, Marija Journal of Nervures SPSS Inc, Chicago, 2011;Illinis.

71.Stansby ME. Properties of fish oils and their application to handling of fish and to nutritional and industrial use. In: Martin RE, Flick GJ, Hebard CE and Ward DR Eds. Chemistry and Biochemistry of marine food products. Ayi Publishing Co. Westport. 1982;75-92.

72.Tam NFY, Wong YS. Spatial variation of heavy metals in surface sediments of Hong Kong mangrove swamps. Environmental Pollution. 2000;110(2):195-205.

73.Tawari-Fufeyin P, Ekaye SA. Fish species diversity as indicator of pollution in Ikpoba river, Benin City, Nigeria. Reviews in Fish Biology and Fisheries. 2007;17(1): 21-30.

74.Wariaghli F, Tigillimann A, El Abidi A, El Hamri H, Fekhaoui M, Yahyaoui A. Evaluation of the degree of heavy metals contamination in the Sebou Estuary and in Moulay Bousselham reserve. International Journal of Aquatic Science. 2013;4(2): 69-82.

75.Wegwu MO, Akaninwor JO. Assessment of heavy-metal profile of the New Calabar River and its impact on juvenile Clarias gariepinus. Chem Biodivers. 2006;3(1):79-87.

76.Weatherley AH, Gill HS. The Biology of Fish Growth. Academic press, London. 1987.

77.Willams R, Halwart M, Barg A. Integrating fisheries and agriculture to enhance fish production and food security. FAO Aquacult. Newslett. 1988;20:3-12.

78.WHO, 1985. World Health Organization guidelines for drinking water quality (ii): Health Criteria and supporting information WHO, Geneva, Switzerland.

79.WHO, 1996. World Health Organization guideline values for contaminants in water: Guidelines for Drinking-Water Quality-Second Edition-Volume 2-Health Criteria and Other Supporting Information 971 pp.

80.Yilmaz $\mathrm{AB}$. Levels of heavy metals ( $\mathrm{Fe}, \mathrm{Cu}, \mathrm{Ni}, \mathrm{Cr}, \mathrm{Pb}$ and $\mathrm{Zn}$ ) in tissues of Mugil cephalus and Trachurus mediterraneus from Iskenderun Bay, Turkey. Environmental Research. 2003;92(3):277-281.

81.Yilmaz F, Ozdemir N, Demirak A, Tuna AL. Heavy metal levels in two fish species Leuciscus cephalus and Lepomis gibbous. Food Chemistry. 2007;100(2):830-835. 